\title{
Everolimus as a new potential antiproliferative agent in aggressive human bronchial carcinoids
}

\author{
Maria Chiara Zatelli, Mariella Minoia, Chiara Martini ${ }^{1}$, Federico Tagliati, \\ Maria Rosaria Ambrosio, Marco Schiavon ${ }^{2}$, Mattia Buratto, Fiorella Calabrese ${ }^{3}$, \\ Erica Gentilin, Giorgio Cavallesco ${ }^{4}$, Lisa Berdondini, Federico Rea ${ }^{2}$ \\ and Ettore $C$ degli Uberti
}

Section of Endocrinology, Department of Biomedical Sciences and Advanced Therapies, University of Ferrara, Via Savonarola 9, 44121 Ferrara, Italy

Departments of ${ }^{1}$ Medical and Surgical Sciences, ${ }^{2}$ Thoracic Surgery and ${ }^{3}$ Diagnostic Medical Sciences and Special Therapies, University of Padova, Via Giustiniani 2, 35100 Padova, Italy

${ }^{4}$ Institute of Clinical Surgery, University of Ferrara, Via Savonarola 9, 44121 Ferrara, Italy

(Correspondence should be addressed to E C degli Uberti; Email: dut@unife.it)

\begin{abstract}
Bronchial carcinoids (BCs) are rare tumors originating from endocrine cells dispersed in the respiratory epithelium. It has been previously demonstrated that everolimus, or RAD001, an mTOR inhibitor, has potent antiproliferative effects in human endocrine tumors. Our aim was to evaluate the possible antiproliferative effects of everolimus in human BCs in primary culture. We collected 24 BCs that were dispersed in primary cultures, treated without or with $1 \mathrm{nM}-1 \mu \mathrm{M}$ everolimus, $10 \mathrm{nM}$ SOM230 (pasireotide, a somatostatin receptor multiligand), and/or $50 \mathrm{nM}$ IGF1. Cell viability was evaluated after $48 \mathrm{~h}$, and chromogranin $\mathrm{A}(\mathrm{CgA})$ as well as vascular endothelial growth factor (VEGF) secretion was assessed after $8 \mathrm{~h}$ incubation. Somatostatin receptors, mTOR, and AKT expression were investigated by quantitative PCR. We found that in 15 cultures (67.5\%), everolimus significantly reduced cell viability (by $\sim 30 \% ; P<0.05$ versus control), inhibited p70S6K activity $(-30 \%)$, and blocked IGF1 proliferative effects. Everolimus also significantly reduced CgA (by $\sim 20 \%$ ) and VEGF (by $\sim 15 \%$ ) secretion. Cotreatment with SOM230 did not exert additive effects on cell viability and secretory activity. AKT expression was similar in responder and nonresponder tissues, while mTOR expression was significantly higher in the responder group, which was characterized by higher $\mathrm{CgA}$ plasma levels and bigger tumors with higher mitotic index and angiogenesis. Our data demonstrate that everolimus reduces VEGF secretion and cell viability in BCs with a mechanism likely involving IGF1 signaling, suggesting that it might represent a possible medical treatment for BCs.
\end{abstract}

Endocrine-Related Cancer (2010) 17 719-729

\section{Introduction}

Well-differentiated bronchial neuroendocrine tumors, also referred to as bronchial carcinoids (BCs), are rare tumors accounting for $\sim 25 \%$ of all neuroendocrine tumors, representing $1-2 \%$ of all lung cancers. Localized tumors are treated with conservative surgery, while standard therapy for metastatic lung carcinoids is represented by cytotoxic treatment after surgical resection (Oberg \& Jelic 2009). Treatment with somatostatin (somatotroph inhibitory factor, SRIF) analogs has been widely employed to reduce symptoms due to uncontrolled hormonal secretion, and radiometabolic therapy can also be an option (Gustafsson et al. 2008). BCs have been reported to express c-kit, platelet-derived, and epithelial growth factor receptors, suggesting that treatment with tyrosine kinase receptor inhibitors may be of utility (Granberg et al. 2006), but few clinical data are available so far (Bertino et al. 2009). Since available medical treatments for advanced $\mathrm{BCs}$ are rarely effective in reducing tumor growth 
(Oberg \& Jelic 2009), new therapeutic strategies are needed especially for aggressive tumors that cannot be radically treated with surgery. Everolimus, or RAD001, a novel oral mTOR inhibitor, has been recently employed in neuroendocrine tumors, including also few primary lung tumors, showing disease stabilization (Yao et al. 2008). These patients were also treated with octreotide, a SRIF analog having affinity for two of the five SRIF receptors (SSTR2 and SSTR5). This drug has been shown to reduce serum insulin-like growth factor 1 (IGF1) levels in patients with solid tumors (Pollak et al. 1989). Moreover, it has been previously indicated that upregulation of IGF pathway, which is upstream of mTOR, could represent a potential resistance mechanism for everolimus (O'Reilly et al. 2006). The aim of our study is therefore to verify the effects of everolimus in a group of 24 human BCs in vitro, in combination with a new SRIF analog, SOM230 (pasireotide) interacting with four of the five SSTRs, also exploring the possible interactions with IGF1 signaling. We also investigated the possible predicting factors of tumor responsiveness to mTOR inhibitors.

\section{Materials and methods}

\section{Materials}

All reagents, if not otherwise specified, were purchased from Sigma-Aldrich. Everolimus and SOM230 (pasireotide) were provided by Novartis Pharma.

\section{Human BCs}

The samples derived from 24 patients, whose characteristics are shown in Table 1, diagnosed and operated on for BCs between 2007 and 2009 at the University of Ferrara (Section of Endocrinology and Institute of Surgery), and at the University of Padova (Department of Medical and Surgical Sciences and Department of Thoracic Surgery). All patients (14 males and 10 females; age $=51.5 \pm 3.1$ years) underwent $\mathrm{BC}$ resection, and had histological and immunohistochemical diagnosis of typical BC in 19 patients and of atypical BC in five patients, according to WHO classification (Travis \& Brambilla 2004).

\section{Tissue collection and primary culture}

Tissues were collected following the guidelines of the local committee on human research, and immediately minced in RPMI 1640 medium under sterile conditions, as described. Primary cultures were then prepared as described previously (Zatelli et al. 2005).
Table 1 Patients characteristics

\begin{tabular}{|c|c|c|c|c|}
\hline Patient & Age & Sex & Diagnosis & TNM \\
\hline 1 & 49 & $\mathrm{~F}$ & Typical & T2N2 \\
\hline 2 & 36 & $\mathrm{~F}$ & Atypical & T2N1 \\
\hline 3 & 49 & $\mathrm{~F}$ & Typical & T3N0 \\
\hline 4 & 29 & $M$ & Typical & T2No \\
\hline 5 & 45 & $\mathrm{M}$ & Typical & T2NO \\
\hline 6 & 52 & $M$ & Typical & T1N0 \\
\hline 7 & 36 & $\mathrm{~F}$ & Typical & T2N1 \\
\hline 8 & 74 & $\mathrm{~F}$ & Typical & T1N0 \\
\hline 9 & 68 & $M$ & Atypical & T2No \\
\hline 10 & 39 & $M$ & Atypical & T3N0 \\
\hline 11 & 47 & $\mathrm{~F}$ & Typical & T2No \\
\hline 12 & 76 & $M$ & Typical & $\mathrm{T} 1 \mathrm{~N} 1$ \\
\hline 13 & 42 & $M$ & Typical & T2N0 \\
\hline 14 & 30 & $M$ & Typical & T2NO \\
\hline 15 & 72 & $\mathrm{~F}$ & Typical & T1N0 \\
\hline 16 & 72 & $M$ & Typical & T1N1 \\
\hline 17 & 39 & $\mathrm{~F}$ & Typical & T2NO \\
\hline 18 & 72 & $M$ & Typical & $\mathrm{T} 1 \mathrm{~N} 1$ \\
\hline 19 & 68 & $\mathrm{M}$ & Typical & T2NO \\
\hline 20 & 41 & $M$ & Atypical & T3NO \\
\hline 21 & 50 & $\mathrm{~F}$ & Typical & T1N0 \\
\hline 22 & 57 & $M$ & Typical & T2N1 \\
\hline 23 & 45 & $M$ & Typical & T1N0 \\
\hline 24 & 49 & $\mathrm{~F}$ & Atypical & T2N0 \\
\hline
\end{tabular}

Informed consent of the patients was obtained for disclosing clinical investigation and performing the in vitro study.

\section{Cell viability}

The effects of everolimus, IGF1, and SOM230 (pasireotide, a SSTR multiligand; Bruns et al. 2002) were tested on BC primary cultured cells, plated in 96-well plates at $2 \times 10^{4}$ cells/well, and treated after $24 \mathrm{~h}$ without or with the test substances. Treatments were renewed after the first $24 \mathrm{~h}$ of incubation. Cell viability was assessed after $48 \mathrm{~h}$ by the TACS 3-(4,5dimethylthiazol-2-yl)-2,5-diphenyltetrazolium bromide (MTT) cell proliferation assay (Trevigen, Gaithersburg, MD, USA), as described previously (Zatelli et al. 2010) using the Wallac Victor 1420 Multilabel Counter (Perkin-Elmer, Monza, Italy). Results (absorbance at $490 \mathrm{~nm}$ ) were obtained by determining the mean value of eight replicates.

\section{Fluorescence microscopy}

IGF1 receptor (IGF1R) immunofluorescence was performed as previously described (Zatelli et al. 2009), by using a goat anti-human IGF1R antibody ( $1 \mu \mathrm{g} / \mathrm{ml}$; Sigma-Aldrich) and a secondary tetramethyl rhodamine isothiocyanate (TRITC)-conjugated mouse anti-goat antibody (1:200 v/v; Invitrogen Molecular 
Probes). Slides were mounted with the ProLong Gold antifade reagent (Invitrogen Molecular Probes) containing the nuclear stain $4^{\prime}, 6^{\prime}$-diamidino-2-phenylindole (DAPI) under glass cover slips (Menzel-Glaser, Braunschweig, Germany). The slides were visualized with the Nikon Eclipse TE2000-U fluorescent microscope, photographed with a $\times 60$ objective magnification with the DS-5M Nikon color CCD digital camera, and analyzed with the Multi-Analyst software (Bio-Rad). Preimmune serum and antigenabsorbed antibody were used as controls.

\section{p70S6K activity assay}

Kinase activity of p70S6K was evaluated by the p70S6K Activity Assay Kit (Assay Designs, Inc., Ann Arbor, MI, USA), as previously described (Zatelli et al. 2010). Cells, plated at $10^{6}$ cells/well in $10-\mathrm{cm}$ dishes, were treated after $24 \mathrm{~h}$ without or with the test substances. After $48 \mathrm{~h}$, total proteins were isolated, using $600 \mathrm{ng}$ proteins for each sample to evaluate p70S6K kinase activity. The absorbance at $450 \mathrm{~nm}$ was recorded using the Wallac Victor 1420 Multilabel Counter (Perkin-Elmer). Results were obtained by determining the mean value of six replicates.

\section{Isolation of RNA and RT-PCR}

RT-PCR analysis for chromogranin $\mathrm{A}(\mathrm{CgA})$ expression was performed on each specimen, and gene expression was analyzed only in CgA-expressing tissues, as previously described (Zatelli et al. 2005). Briefly, total RNA was isolated from tissues with TRIzol reagent (Invitrogen) and treated with RNase-free DNase (Promega). Reverse transcription and PCRs were carried out as previously described (Zatelli et al. 2005). Human $\beta$-actin (ACTB) amplification was performed as control for RT reaction.

\section{Quantitative PCR for mTOR, AKT, and SSTRS mRNA}

Relative quantitative PCR (RQ-PCR) for assessing mTOR and AKT expression was performed using TaqMan gene expression assays (mTOR Hs00234522_m1; AKT1 Hs00178289_m1; Applied Biosystems, Monza, Italy). 18s rRNA (4319413E TaqMan Endogenous Control; Applied Biosystems) was used as reference gene. Results are expressed as the fold difference of gene expression level in responder tissues versus a pool of nonresponder tissues (calibrator). We performed at least five independent experiments in three replicates.
Q-PCR for SSTR subtype 1, SSTR2, SSTR3, SSTR4, and SSTR5 was performed as previously described (Zatelli et al. 2010). The Pre-Developed TaqMan Assay Reagents for huGUS (Applied Biosystems) was used to asses reverse transcription efficiency, with slopes $-3.3 \pm 0.1$ for all assays. In each experiment, no template control and RT controls were run, and a cutoff of $3 \times 10^{3} \mathrm{mRNA}$ copies/ $\mu \mathrm{g}$ total RNA was considered as the threshold for Q-PCR to exclude the detection of transcripts due to illegitimate transcription (Chelly et al. 1989, Korbonits et al. 2001). SSTR tissue expression was also confirmed by immunohistochemistry, performed as previously described (Bondanelli et al. 2005). All RQ-PCR and Q-PCRs were performed, recorded, and analyzed using the ABI 7700 Prism sequence detection system (Applied Biosystems).

\section{$\mathrm{CgA}$ and vascular endothelial growth factor assays}

$\mathrm{CgA}$ and vascular endothelial growth factor (VEGF) were measured in conditioned medium from primary cultured cells $\left(2 \times 10^{4}\right.$ cells/well in eight replicates) after a 8-h treatment without or with the test substances with an ELISA kit specific for CgA (Dako, Milano, Italy) and one for VEGF (Pierce Biotechnology, Inc., Rockford, IL, USA) respectively as previously described (Zatelli et al. 2004, 2007). Assays were performed in duplicate after appropriate medium dilution. Results were obtained by determining the mean value among eight replicates.

\section{Western blot analysis}

Total cell lysates were obtained from homogenized BC. Protein extracts resolved by SDS-PAGE as previously described (Tagliati et al. 2006) were probed with different antibodies: anti-mTOR, anti-phospho mTOR (Euroclone, Milano, Italy), anti-p70S6K1, antiphospho p70S6K1 (Santa Cruz Biotechnology, Heidelberg, Germany), and anti-actin (Sigma-Aldrich). Immunoreactive proteins were visualized by enhanced chemiluminescence (Amersham International).

\section{Statistical analysis}

Results are expressed as the mean \pm s.E.M. A test for multiple comparisons (Student Newman-Keuls) was used to evaluate individual differences between means. The $\chi^{2}$ and one-way ANOVA tests were used to compare clinico-pathological and molecular data of responder with those of nonresponder primary cultures, setting the level of statistical significance at $P=0.05$. 


\section{Results}

\section{Effects of everolimus on cell viability}

To determine the effects of everolimus on cell viability of dispersed BC cells, BC primary cultures were treated for $48 \mathrm{~h}$ with everolimus at concentrations from $1 \mathrm{nM}$ to $1 \mu \mathrm{M}$. As shown in Fig. 1A, when considered as a whole group, human BC primary cultures displayed a modest response to everolimus in terms of cell viability reduction (gray bars). Indeed, everolimus slightly but significantly reduced cell viability at $10 \mathrm{nM}(-7.7 \% ; P<0.05)$ and at $100 \mathrm{nM}(-10.7 \%$; $P<0.05)$, but not at $1 \mu \mathrm{M}$. Therefore, the whole group was divided into primary cultures displaying each a significant $(P<0.05)$ cell viability reduction under everolimus treatment, referred to as 'responders', and those that did not, referred to as 'nonresponders'.

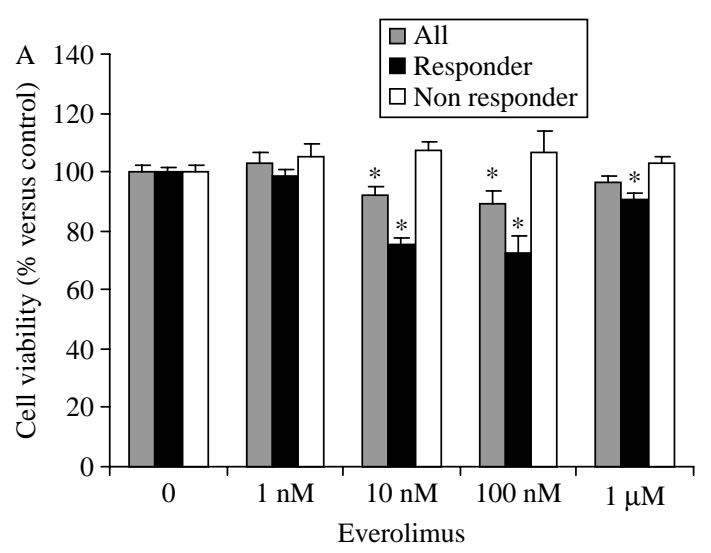

B

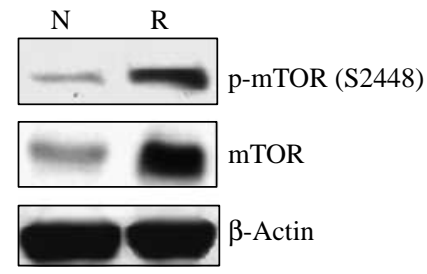

Figure 1 Effects of everolimus on cell viability and mTOR expression in BC. (A) BC cells were incubated in 96-well plates for $48 \mathrm{~h}$ in culture medium supplemented with everolimus at increasing concentrations from $1 \mathrm{nM}$ to $1 \mu \mathrm{M}$, and control cells were treated with vehicle solution. Cell viability of each primary culture was measured as absorbance at $490 \mathrm{~nm}$. As described in the Results section, samples were divided according to cell viability inhibition after treatment with everolimus in responders (15 samples, black bars) and nonresponders (nine samples, white bars). Data from BC primary cultures were evaluated independently with eight replicates each, and were expressed as the mean \pm S.E.M. percent cell viability inhibition versus untreated control cells. ${ }^{*} P<0.05$ versus untreated control cells. (B) Western blot analysis for total (mTOR) and phosphorylated (p-mTOR) mTOR in a pool of five nonresponder (N) and a pool of five responder $(\mathrm{R}) \mathrm{BC}$. Actin is shown as a loading control.
According to this criterion, cultures from $15 \mathrm{BCs}$ were considered as 'responders', and cultures from nine BCs were considered as 'nonresponders'. As shown in Fig. 1A, in the responders group (black bars), everolimus significantly $(P<0.05)$ reduced cell viability at $10 \mathrm{nM}(-24.4 \%)$, at $100 \mathrm{nM}(-27.8 \%)$, and at $1 \mu \mathrm{M}$ $(-9.3 \%)$. In the nonresponder BCs (white bars), everolimus did not significantly modify cell viability at any concentration. Further experiments were carried out only in the 'responders' group.

\section{Differential features between responder and nonresponder BCs to everolimus}

As shown in Table 2, no difference was found between responders and nonresponders $\mathrm{BC}$ concerning age, gender, tumor site, smoking habit, TNM staging, and immunohistochemical staining for $\mathrm{CgA}$, neuron specific enolase (NSE), synaptophysin, or ki67 labeling index. Whereas, maximal tumor diameter and percentage lymph node metastases were significantly greater in responders as compared with nonresponders BC. All but one responder tumor showed octreoscan positivity preoperatively. The 15 responder tumors were histologically diagnosed as typical in ten cases and as atypical in five cases, while all the nonresponders tumors were consistent with typical carcinoids. Moreover, responder tissues had a significantly $(P<0.05)$ higher number of mitoses and a 1.7-fold higher score for the angiogenetic marker CD105. CgA and P polypeptide (PP) circulating levels were significantly approximately six- and two-fold higher in patients with responder as compared with nonresponders $\mathrm{BC}$ respectively. Gene expression analysis showed that mTOR mRNA expression was much higher in responder tumors as compared with nonresponders BC. Accordingly, a higher level of total and phosphorylated mTOR protein was found in responder as compared with nonresponder BC (Fig. 1B). On the other hand, AKT mRNA expression was highly variable in both groups, and therefore, no significant difference could be appreciated. VEGF and its receptors were expressed only in a minority of BC, without differences between responder and nonresponder tumors (not shown).

Taken together, these findings indicate that responder tissues display more aggressive features and a higher expression of the molecular target of everolimus, mTOR, as compared with nonresponder tissues.

\section{Effects of IGF1 on cell viability}

To analyse the possible effects of IGF1 on primary BC cultures, we first demonstrated that IGF1R is indeed expressed in BC dispersed cells (Fig. 2A). In addition, 
Table 2 Bronchial carcinoid characteristics according to response to everolimus

\begin{tabular}{llll}
\hline & Responders & Nonresponders & $\begin{array}{l}\boldsymbol{P} \text { (responders versus } \\
\text { nonresponders }\end{array}$ \\
\hline Age & $53 \pm 5.4$ & $48 \pm 4.7$ & $\mathrm{NS}$ \\
Gender (M/F) & $8 / 7$ & $5 / 4$ & $\mathrm{NS}$ \\
Smoking history (yes/no) & $6 / 9$ & $4 / 5$ & $\mathrm{NS}$ \\
Diameter (cm) & $3.6 \pm 0.4$ & $2.16 \pm 0.3$ & $<0.05$ \\
Lymph node metastases (\%) & 10.4 & 3.1 & $<0.02$ \\
Typical/atypical & $10 / 5$ & $9 / 0$ & $<0.05$ \\
Mitotic figures/mm ${ }^{2}$ & $1.7 \pm 0.2$ & $0.8 \pm 0.1$ & $<0.01$ \\
CD105 (counts/mm ${ }^{2}$ ) & $43.3 \pm 9$ & $25.3 \pm 4.3$ & $<0.05$ \\
Plasma CgA levels (ng/ml) & $496.8 \pm 144$ & $57.6 \pm 2.1$ & $<0.05$ \\
Plasma PP levels (ng/l) & $116.6 \pm 21$ & $51.2 \pm 7.6$ & $<0.05$ \\
mTOR mRNA expression & 900 & 1 & $<0.01$ \\
$\quad$ (fold versus nonresponders) & & & \\
\hline
\end{tabular}

incubation with an anti-IGF1R antibody determined a significant reduction in basal cell viability $(-21 \%$; $P<0.01)$ and blocked the stimulatory effects of IGF1 on this parameter, underlining the importance of serum IGF1 in BC cell viability in vitro (Fig. 2B). To investigate whether everolimus inhibitory effects might involve pathways activated by growth factors,
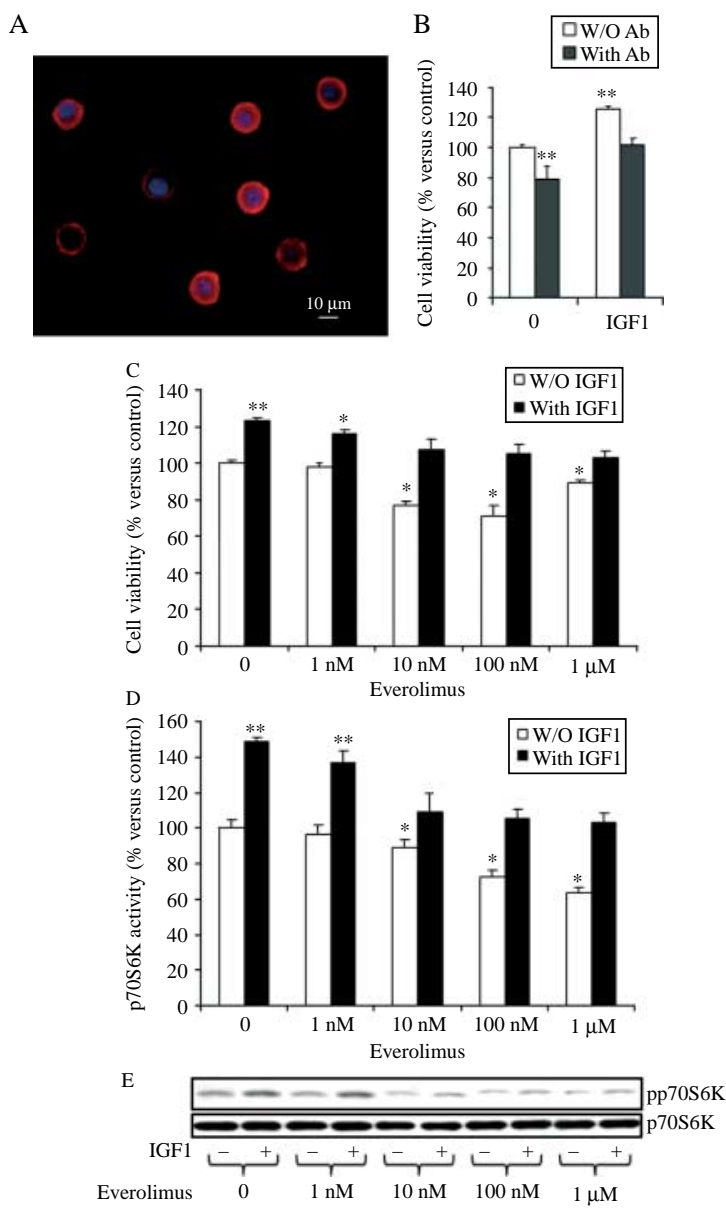

$\begin{array}{llllll}\text { Everolimus } \quad 0 & 1 \mathrm{nM} & 10 \mathrm{nM} & 100 \mathrm{nM} & 1 \mu \mathrm{M}\end{array}$ such as IGF1, cell viability was assessed in the responder $\mathrm{BC}$ cultures treated with or without $50 \mathrm{nM}$ IGF1, in the presence or in the absence of everolimus at $1 \mathrm{nM}-1 \mu \mathrm{M}$. IGF1 significantly promoted cell viability $(+23 \% ; P<0.01)$, an effect that was completely abolished by everolimus at concentrations $\geq 10 \mathrm{nM}$ (Fig. 2C).

Figure 2 IGF1 receptor and p70S6K expression and effects of IGF1 on BC cell viability. (A) IGF1 receptor expression: primary cultured $\mathrm{BC}$ cells were grown in culture medium and then incubated with the specific IGF1R antibody, fixed, incubated with the secondary TRITC-conjugated antibody, mounted with the antifade reagent containing DAPI, and photographed with a $\times 60$ objective magnification. The experiment was carried out in duplicate at least three times independently, and $50 \pm 10$ individual cells have been analyzed. Overlay image shows BC cells observed with the TRITC filter, revealing membrane immunofluorescence, and with the u.v. filter, revealing nuclear immunofluorescence. (B) BC cells were incubated for $48 \mathrm{~h}$ in culture medium in the presence or in the absence of an IGF1R antibody, supplemented with or without 50 nM IGF1. Control cells were treated with vehicle solution. Cell viability of each primary culture was measured as absorbance at $490 \mathrm{~nm}$. Data from BC primary cultures were evaluated independently with eight replicates each, and were expressed as the mean \pm S.E.M. percent cell viability inhibition versus untreated control cells. ${ }^{\star \star} P<0.01$ versus untreated control cells. (C) BC cells were incubated for $48 \mathrm{~h}$ in culture medium supplemented with $1 \mathrm{nM}-1 \mu \mathrm{M}$ everolimus, in the presence or in the absence of 50 nM IGF1. Control cells were treated with vehicle solution. Cell viability of each primary culture was measured as absorbance at $490 \mathrm{~nm}$. Data from BC primary cultures were evaluated independently with eight replicates each, and were expressed as the mean \pm S.E.M. percent cell viability inhibition versus untreated control cells. ${ }^{*} P<0.05$ and ${ }^{\star \star} P<0.01$ versus untreated control cells. (D) BC cells were incubated for $48 \mathrm{~h}$ in culture medium supplemented with $1 \mathrm{nM}-1 \mu \mathrm{M}$ everolimus, in the presence or in the absence of $50 \mathrm{nM}$ IGF1. Control cells were treated with vehicle solution. p70S6K activity was measured as absorbance at $450 \mathrm{~nm}$. Results are expressed as mean value \pm S.E.M.

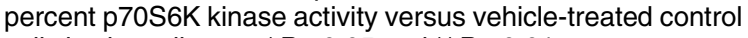
cells in six replicates. ${ }^{*} P<0.05$ and ${ }^{* *} P<0.01$ versus untreated control cells. (E) Western blotting for phosphorylated (pp70S6K) and total p70S6K (p70S6K) on total cell lysates from a pool of responder $\mathrm{BC}$ cells treated with $1 \mathrm{nM}-1 \mu \mathrm{M}$ everolimus in the presence $(+)$ or in the absence $(-)$ of IGF1 $50 \mathrm{nM}$. 


\section{Effects of everolimus on p70S6K activity}

To evaluate whether the effects of everolimus are related to mTOR inhibition, we evaluated the kinase activity of p70S6K, one of the main downstream effectors of mTOR. The responder BC primary cultures were treated for $48 \mathrm{~h}$ with or without $50 \mathrm{nM}$ IGF1, in the presence or in the absence of everolimus at $1 \mathrm{nM}-1 \mu \mathrm{M}$. Everolimus at concentrations $\geq 10 \mathrm{nM}$ significantly and dose-dependently reduced p70S6K activity (from -10.8 to $-36.6 \% ; P<0.05$ ). On the other hand, IGF1 significantly induced p70S6K activity $(+49 \% ; P<0.01)$, an effect that was completely blocked by coincubation with everolimus $\geq 10 \mathrm{nM}$ (Fig. 2D). Western blot analysis for total (p70S6K) and phosphorylated (pp70S6K) p70S6K confirmed these findings, showing that everolimus dose-dependently reduced p70S6K phosphorylation and was capable of blunting the stimulatory effects of IGF1 on this parameter (Fig. 2E).

\section{Effects SOM230 on cell viability}

We also evaluated the possible cooperative effects of everolimus with a SSTR pan-agonist, SOM230. First of all, we assessed SSTR expression in the $15 \mathrm{BCs}$ responding to everolimus (Fig. 3). SSTR1 was expressed in seven tissues (47\%), with the highest expression level among all SSTRs $\left(39.5 \times 10^{4}\right.$ mRNA molecules/ $\mu \mathrm{g}$ of reverse-transcribed total RNA). SSTR2 $\left(9 \times 10^{4}\right.$ mRNA molecules/ $\mu \mathrm{g}$ of reversetranscribed total RNA) was expressed in 14 tissues

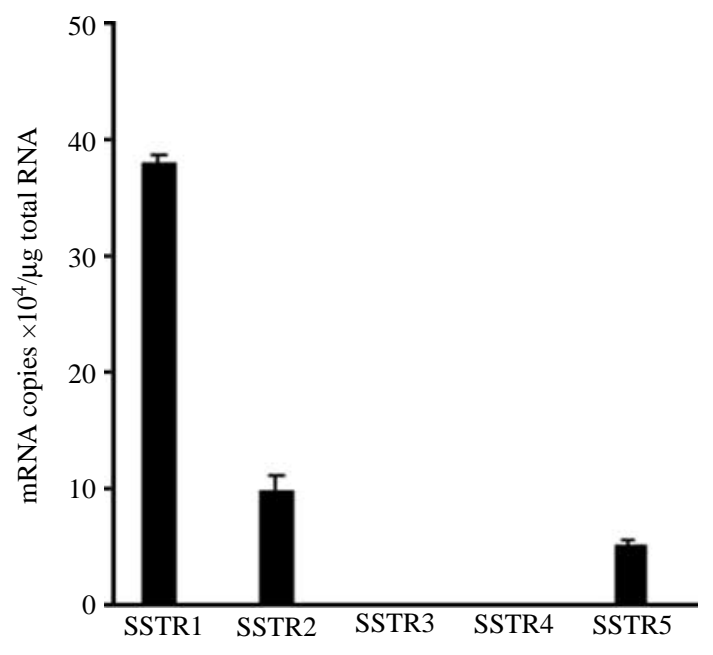

Figure 3 SSTR expression in responder BC. QPCR was performed for investigating SSTR1-5 expression in responder BC. Total RNA was isolated, and QPCR performed as described in the Materials and methods section. Results are expressed as mean SSTR1-5 mRNA molecules $10^{4} / \mu \mathrm{g}$ total RNA \pm S.E.M.
(93\%), while expression of SSTR3 and SSTR4 was below the detection threshold level $\left(<3 \times 10^{3}\right.$ mRNA molecules/ $\mu \mathrm{g}$ of reverse-transcribed total RNA). SSTR5 was expressed in six tissues (40\%), with an expression level $\left(3 \times 10^{4}\right.$ mRNA molecules/ $\mu \mathrm{g}$ of reverse-transcribed total RNA) much lower as compared with SSTR1 and SSTR2. Qualitative data on SSTR tissue expression were also confirmed by immunohistochemical studies.

Preliminary experiments showed that $100 \mathrm{nM}$ was the lowest SOM230 concentration which significantly reduced in vitro cell viability of human BCs (not shown). As shown in Fig. 4A, treatment with $100 \mathrm{nM}$ SOM230 determined a slight but significant reduction in cell viability $(-10.3 \% ; P<0.05)$; however, SOM230 did not enhance the inhibitory effects of everolimus at any concentration tested.

\section{Effects of everolimus on CgA and VEGF secretion}

To determine the effects of everolimus on $\mathrm{CgA}$ and VEGF secretion by dispersed BC cells, we assessed $\mathrm{CgA}$ and VEGF concentrations in conditioned medium from the $15 \mathrm{BC}$ primary cultures responding to everolimus.

Basal CgA levels in the culture medium (6.9 $\pm 1.1 \mathrm{ng} / \mathrm{ml})$ were slightly but significantly $(P<0.05)$ reduced by treatment with everolimus at $10 \mathrm{nM}$ $(-10.6 \%)$ and at $100 \mathrm{nM}(-18.7 \%)$. SOM230 at $100 \mathrm{nM}$ as well significantly reduced $\mathrm{CgA}$ secretion $(-12.7 \%$; $P<0.05)$, an effect that was not significantly enhanced by cotreatment with any everolimus concentration (Fig. 4B).

Basal VEGF levels in the culture medium (16.3 $\pm 1.8 \mathrm{pg} / \mathrm{ml}$ ) were slightly but significantly reduced by treatment with everolimus at $10 \mathrm{nM}(-12.6 \%$; $P<0.05)$ and at $100 \mathrm{nM}(-15.8 \% ; P<0.05)$. SOM230 at $100 \mathrm{nM}$ as well significantly reduced VEGF secretion $(-16.4 \% ; P<0.05)$, an effect that was not enhanced by cotreatment with any everolimus concentration (Fig. 4C).

\section{Discussion}

We here show that everolimus, a novel oral mTOR inhibitor, can effectively reduce both cell viability and $\mathrm{CgA}$ and VEGF secretion in a group of clinically and histologically aggressive $\mathrm{BC}$ in vitro. Our results provide the biological basis for the already reported efficacy of everolimus in disease stabilization in a small group of patients with primary lung neuroendocrine tumors (Yao et al. 2008). The involvement of the mTOR pathway in BC has been previously suggested 
by the reported high expression of mTOR and its effector, p70S6K, in a series of metastatic typical BC (Righi et al. 2010). Our data are in line with this evidence, since we demonstrate that mTOR is expressed in $\mathrm{BC}$, mostly in tissues responding to everolimus with a reduction in p70S6K activity, indicating that the mTOR pathway is activated in BC. However, the finding that everolimus at $1 \mu \mathrm{M}$ reduces cell viability to a lesser extent than at $100 \mathrm{nM}$ while p70S6K is further reduced, may indicate that this drug may activate other pathways, such as AKT itself or ERK pathway, as previously reported (Abrams et al. 2010). These pathways, in turn, may protect BC cells from the inhibitory effects of everolimus.
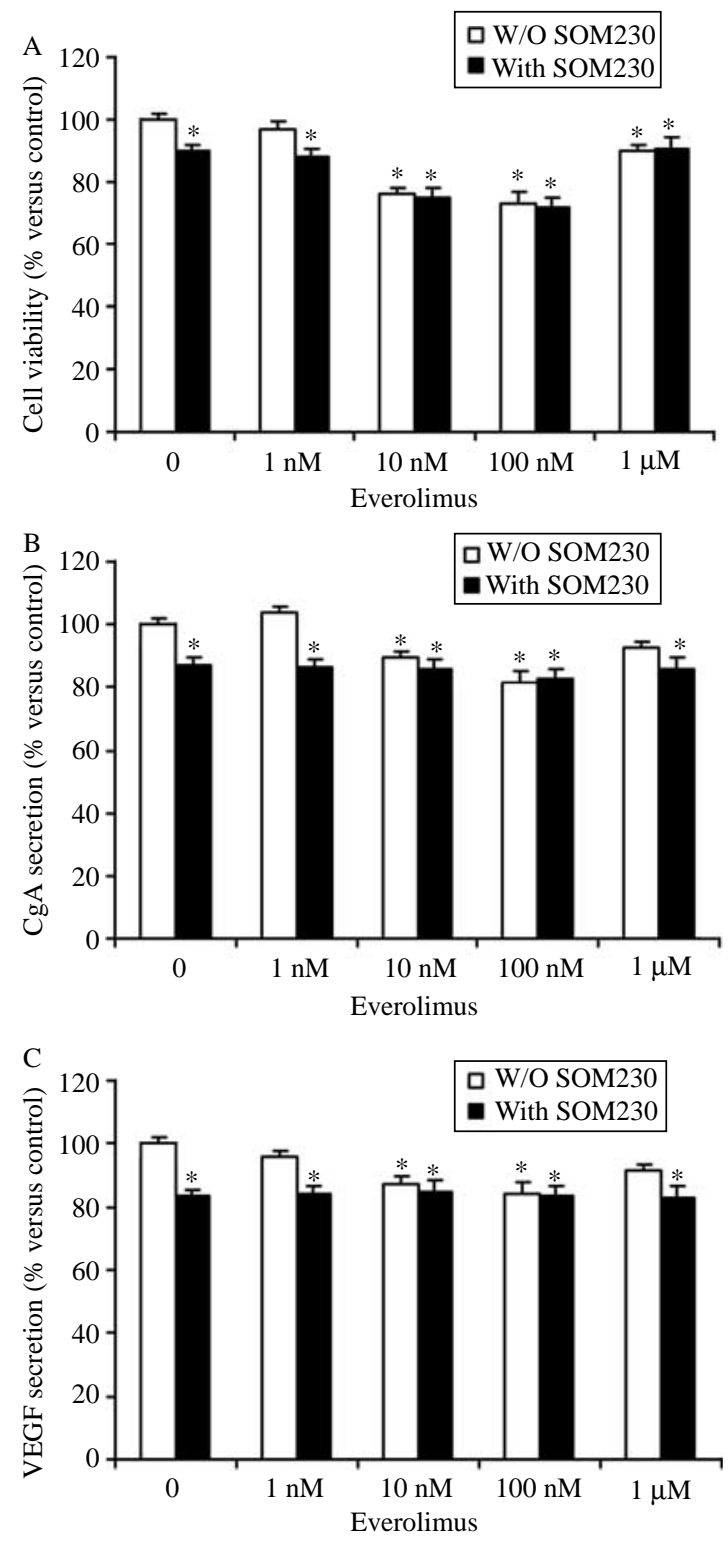

Our results also show that IGF1 can promote in vitro BC cell viability, suggesting that IGF1 downstream signaling may be important in controlling $\mathrm{BC}$ growth, as also indicated by the evidence that IGF1R blockade reduces basal and IGF1 stimulated BC cell viability. Moreover, the evidence that everolimus downregulates the response of BC primary cultures to IGF1 in terms of p70S6K activity indicates that everolimus might control BC proliferation by hampering IGF1 downstream signaling. The important role for IGF1 and its receptors in the control of neuroendocrine tumor proliferation is underlined by the evidence of a high or constitutive expression of IGF1, IGF2, and IGF receptors in gastroenteropancreatic neuroendocrine tumors (GEP-NETs; Wulbrand et al. 2000). In addition, IGF1-dependent signaling has been demonstrated to promote tumorigenesis and to increase hormonal secretion in a GEP-NET cell line (Grozinsky-Glasberg et al. 2008). We here report for the first time the evidence for IGF1R expression and for a possible proliferative role of IGF1 also in BC cells.

In our settings, everolimus significantly reduced cell viability in $62.5 \%$ of the examined tumors, which displayed clinical and histological characteristics of greater aggressiveness (approximately twofold greater diameter, approximately threefold higher metastatic rate and approximately twofold higher number of mitoses as compared with $\mathrm{BC}$ not responding to everolimus). These results indicate that aggressive BCs respond to the treatment with mTOR inhibitors,

Figure 4 Effects of SOM230 on BC primary cultures.

(A) Cell viability: $\mathrm{BC}$ primary cultures were treated with either $1 \mathrm{nM}-1 \mu \mathrm{M}$ everolimus alone (white bars) or in combination with $100 \mathrm{nM}$ SOM230 (black bars). Cell viability of each primary culture was measured after $48 \mathrm{~h}$ as absorbance at $490 \mathrm{~nm}$. Data from BC primary cultures were evaluated independently with eight replicates each, and were expressed as the mean \pm s.E.M. percent cell viability inhibition or induction versus untreated control cells. ${ }^{\star} P<0.05$ versus untreated control cells. (B) $\mathrm{CgA}$ secretion: $\mathrm{BC}$ cells were incubated in 96-well plates for $8 \mathrm{~h}$ in culture medium supplemented with either $1 \mathrm{nM}-1 \mu \mathrm{M}$ everolimus alone (white bars) or in combination with $100 \mathrm{nM}$ SOM230 (black bars). Control cells were treated with vehicle solution. $\mathrm{CgA}$ secretion by each primary culture was then measured by ELISA. Data from BC primary cultures were evaluated independently with eight replicates each, and were expressed as the mean \pm s.E.M. percent $\mathrm{CgA}$ secretion inhibition versus untreated control cells. ${ }^{\star} P<0.05$ versus untreated control cells. (C) VEGF secretion: BC cells were incubated in 96-well plates for $8 \mathrm{~h}$ in culture medium supplemented with either $1 \mathrm{nM}-1 \mu \mathrm{M}$ everolimus alone (white bars) or in combination with $100 \mathrm{nM}$ SOM230 (black bars). Control cells were treated with vehicle solution. VEGF secretion by each primary culture was then measured by ELISA. Data from BC primary cultures were evaluated independently with eight replicates each, and were expressed as the mean \pm S.E.M. percent VEGF secretion inhibition versus untreated control cells. ${ }^{\star} P<0.05$ versus untreated control cell. 
possibly representing an effective therapeutic tool for aggressive unresectable BC. This perspective is clinically important, since BCs show minimal and short-lasting responses to various chemotherapeutic agents (Beasley et al. 2000), being still orphan of an effective medical treatment. In these settings, a reduction in cell viability of nearly $30 \%$, possibly mirroring a reduction in tumor diameter, could be clinically relevant, since it may candidate the patients for a further surgical treatment. The lowest effective everolimus concentration in responder $\mathrm{BC}(10 \mathrm{nM})$ is slightly higher than the therapeutic range recommended $(3-8 \mathrm{nM})$ when everolimus is used as an immunosuppressant drug, at an oral daily dose of $1.5 \mathrm{mg} /$ day (Mabasa \& Ensom 2005). Everolimus is currently employed in clinical trials involving neuroendocrine tumors, such as RADIANT-1 (Yao et al. 2010) at oral daily doses of $10 \mathrm{mg}$, likely achieving much higher plasma concentrations. However, clinical trials are necessary to test the in vivo relevance and the impact on survival of a medical treatment with everolimus in $\mathrm{BC}$.

The greater mTOR expression in the group of responder $\mathrm{BC}$ provides the molecular basis for the efficacy of everolimus, and might explain the resistance of nonresponder $\mathrm{BC}$ to the antiproliferative effects of everolimus, since these tumors express the drug molecular target at lower levels. The higher expression of the angiogenic marker CD105 in the group of $\mathrm{BC}$ responding to everolimus provides a further explanation for the efficacy of mTOR inhibitors, which have been demonstrated to have antiangiogenic properties (Bjornsti \& Houghton 2004). CD105/endoglin, a glycoprotein expressed on the surface of endothelial cells of peri- and intratumor neoformed blood vessels, involved in vascular development and remodeling (Fonsatti et al. 2003), is considered as an efficient marker of angiogenic activity in tumor tissues (Fonsatti \& Maio 2004). Everolimusresponder $\mathrm{BCs}$ display higher angiogenic activity as compared with nonresponder $\mathrm{BC}$, providing a further explanation for their sensitivity to mTOR inhibitors. In addition, these results indicate that CD105 may represent a useful pathological marker to identify tumors more likely to be successfully treated with an antiangiogenic drug, such as everolimus. In keeping with the evidence that neoangiogenesis, quantified by neoformed pathological microvessel density, predicts nodal metastases in typical BC (Das-Neves-Pereira et al. 2008), we found that metastatic lymph nodes were significantly more frequent in tumors responding to everolimus.
It has been previously shown that microvessel density correlates with VEGF (Raica et al. 2009), which is expressed, together with its receptors, also in lung carcinoids (Ambs et al. 1998). However, we failed to demonstrate any difference in VEGF and VEGF-R expression between responder and nonresponder BC. Moreover, only a slight decrease in VEGF secretion in vitro $(<20 \%)$ was observed under everolimus treatment in responder $\mathrm{BC}$, and was not modified by simultaneous treatment with SOM230, at variance with previous evidence reported in nonfunctioning pituitary adenomas (Zatelli et al. 2010). These data suggest that VEGF might not be an optimal marker for identifying patients likely responding to everolimus. On the other hand, the evidence that everolimus can reduce VEGF as well as $\mathrm{CgA}$ secretion underline that this drug might also have antisecretory properties, possibly limiting uncontrolled BC secretory activity. At the same time, our data show that patients bearing responder $\mathrm{BC}$ display higher plasma $\mathrm{CgA}$ and PP levels as compared with nonresponders, suggesting that these parameters might represent predictive factors for in vivo response to everolimus. On the other hand, no difference was found between responder and nonresponder tissues in terms of NSE immunostaining or circulating plasma levels, suggesting that there is no correlation between these parameters and response to everolimus in our experimental model, at variance with what reported for patients with metastatic pancreatic neuroendocrine tumors (Yao et al. 2010).

SRIF analogues are reported to improve the control of carcinoid syndrome (Yao 2007), in keeping with SSTR expression in BC. SSTR2A and SSTR3 expression has been recently investigated in pulmonary endocrine tumors (Righi et al. 2010), showing that these receptors are heterogeneously distributed, with SSTR2 strikingly overexpressed in metastatic typical as compared with atypical and clinically benign BC. Our data also show that SSTR2 is the most frequently expressed SSTR subtype, but its expression is quantitatively lower as compared with SSTR1, which was not investigated by Righi et al. (2010). The evidence that SSTR1 is expressed at high level by almost half of the investigated $\mathrm{BC}$ provides the basis for testing the deriving primary cultures with a SSTR 'pan-agonist', such as SOM230, which binds also to SSTR1, which represents an additional target for this drug. Our data indeed show that treatment with SOM230 has an inhibitory effect on BC cell viability and secretory activity. Currently employed SRIF analogs, such as octreotide an lanreotide, having affinity mostly for SSTR2 and SSTR5, are know as effective treatment to prolong the time to tumor 
progression in patients with functionally active and inactive metastatic midgut neuroendocrine tumors (Rinke et al. 2009) and to reduce hormonal secretion also by bronchial endocrine tumors (Rubin et al. 1999), whereas antitumor effects of SRIF analogues in lung endocrine tumors are still a matter of discussion (Filosso et al. 2002, Srirajaskanthan et al. 2009). Therefore, the finding that the new SRIF analog SOM230 (pasireotide) might be effective in controlling $\mathrm{BC}$ tumor bulk opens new therapeutic perspectives for patients not responding to other medical treatments. However, SOM230 does not exert additive effects with everolimus, both on cell viability and on secretory activity. It should be noted that the antisecretory effects of both SOM230 and everolimus are not related to the inhibitory effects on cell viability, since $\mathrm{CgA}$ and VEGF have been evaluated after a short incubation $(8 \mathrm{~h})$, while the effects on cell viability are apparent after a 48-h incubation. The lack of additive effects under cotreatment with SOM230 and everolimus supports the hypothesis that the two compounds likely transduce their effects by at least partially similar pathways. However, further studies are necessary to elucidate this issue.

In summary, for the first time, we here provide evidence that everolimus reduces cell viability of aggressive $\mathrm{BC}$ in vitro, without cooperative effects with a SRIF analog. We identify putative clinicopathological predictive factors of response to mTOR inhibitors, such as diameter, percentage of metastatic lymph nodes, mitotic figures, angiogenetic markers, and circulating markers ( $\mathrm{CgA}$ and $\mathrm{PP})$, which, however, need validation in clinical trials. Our data indeed indicate that everolimus may represent a possible medical therapy for aggressive and highly vascularized $\mathrm{BC}$.

\section{Declaration of interest}

The authors declare that there is no conflict of interest that could be perceived as prejudicing the impartiality of the research reported.

\section{Funding}

This work was supported by grants from the Italian Ministry of University and Scientific and Technological Research (University of Ferrara: 60\%-2006), Novartis Pharma Italy, Fondazione Cassa di Risparmio di Ferrara, Associazione Italiana per la Ricerca sul Cancro, and Associazione Ferrarese dell'Ipertensione Arteriosa.

\section{Author contribution statement}

M C Zatelli wrote the manuscript, collected, re-elaborated, and matched in vitro and clinical data; M Minoia performed the primary culture studies; C Martini provided clinical and biochemical information for patients from Padova; F Tagliati supervised the Molecular Biology studies and performed western blot analysis; M Rosaria Ambrosio provided clinical and biochemical information for patients from Ferrara; M Schiavon provided surgical and biochemical information for patients from Padova; M Buratto performed the somatostatin receptor expression quantitative studies; F Calabrese performed most of the pathology work-up; E Gentilin performed the mTOR and AKT expression quantitative studies; G Cavallesco provided surgical and biochemical information for patients from Ferrara; L Berdondini performed the hormone assays and the statistical evaluation; F Rea supervised and coordinated the surgical aspects; E C degli Uberti supervised and coordinated the medical aspects.

\section{Acknowledgements}

We thank Novartis Pharma Italy for providing everolimus (RAD001) and SOM230.

\section{References}

Abrams SL, Steelman LS, Shelton JG, Wong EW, Chappell WH, Bäsecke J, Stivala F, Donia M, Nicoletti F, Libra M et al. 2010 The Raf/MEK/ERK pathway can govern drug resistance, apoptosis and sensitivity to targeted therapy. Cell Cycle 9 1781-1791.

Ambs S, Bennett WP, Merriam WG, Ogunfusika MO, Oser SM, Khan MA, Jones RT \& Harris CC 1998 Vascular endothelial growth factor and nitric oxide synthase expression in human lung cancer and the relation to p53. British Journal of Cancer 78 233-239.

Beasley MB, Thunnissen FB, Brambilla E, Hasleton P, Steele R, Hammar SP, Colby TV, Sheppard M, Shimosato Y, Koss MN et al. 2000 Pulmonary atypical carcinoid: predictors of survival in 106 cases. Human Pathology 31 1255-1265.

Bertino EM, Confer PD, Colonna JE, Ross P \& Otterson GA 2009 Pulmonary neuroendocrine/carcinoid tumors: a review article. Cancer 115 4434-4441.

Bjornsti M-A \& Houghton PJ 2004 The TOR pathway: a target for cancer therapy. Nature Reviews. Cancer 4 335-348.

Bondanelli M, Ambrosio MR, Zatelli MC, Cavazzini L, Al Jandali Rifa'y L \& degli Uberti EC 2005 Regression of liver metastases of occult carcinoid tumor with slow release lanreotide therapy. World Journal of

Gastroenterology 11 2041-2044.

Bruns C, Lewis I, Briner U, Meno-Tetang G \& Weckbecker G 2002 SOM230: a novel somatostatin peptidomimetic with broad somatotropin release inhibiting factor (SRIF) receptor binding and a unique antisecretory profile. European Journal of Endocrinology 146 707-716. 
Chelly J, Concordet JP, Kaplan JC \& Kahn A 1989 Illegitimate transcription: transcription of any gene in any cell type. PNAS 86 2617-2621.

Das-Neves-Pereira JC, Bagan P, Milanez-de-Campos JR, Capelozzi VL, Danel C, Jatene FB, Bernaudin JF \& Riquet M 2008 Individual risk prediction of nodal and distant metastasis for patients with typical bronchial carcinoid tumors. European Journal of Cardio-Thoracic Surgery 34 473-478.

Filosso PL, Ruffini E, Oliaro A, Papalia E, Donati G \& Rena O 2002 Long-term serviva of atypical bronchial carcinoids with liver metastases, treated with octreotide. European Journal of Cardio-Thoracic Surgery 21 913-917.

Fonsatti E \& Maio M 2004 Highlights on endoglin (CD105): from basic findings towards clinical applications in human cancer. Journal of Translational Medicine 218.

Fonsatti E, Altomonte M, Nicotra MR, Natali PG \& Maio M 2003 Endoglin (CD105): a powerful therapeutic target on tumorassociated angiogenetic blood vessels. Oncogene 22 6557-6563.

Granberg D, Wilander E \& Oberg K 2006 Expression of tyrosine kinase receptors in lung carcinoids. Tumour Biology 27 153-157.

Grozinsky-Glasberg S, Franchi G, Teng M, Leontiou CA, Ribeiro de Oliveira A Jr, Dalino P, Salahuddin N, Korbonits M \& Grossman AB 2008 Octreotide and the mTOR inhibitor RAD001 (everolimus) block proliferation and interact with the Akt-mTOR-p70S6K pathway in a neuro-endocrine tumour cell line. Neuroendocrinology 87 168-181.

Gustafsson BI, Kidd M, Chan A, Malfertheiner MV \& Modlin IM 2008 Bronchopulmonary neuroendocrine tumors. Cancer 113 5-21.

Korbonits M, Bustin SA, Kojima M, Jordan S, Adams EF, Lowe DG, Kangawa K \& Grossman AB 2001 The expression of the growth hormone secretagogue receptor ligand ghrelin in normal and abnormal human pituitary and other neuroendocrine tumors. Journal of Clinical Endocrinology and Metabolism 86 881-887.

Mabasa VH \& Ensom MH 2005 The role of therapeutic monitoring of everolimus in solid organ transplantation. Therapeutic Drug Monitoring 27 666-676.

Oberg K \& Jelic S 2009 ESMO Guidelines Working Group. Neuroendocrine bronchial and thymic tumors: ESMO clinical recommendation for diagnosis, treatment and follow-up. Annals of Oncology 20 (Suppl 4) 147-149.

O'Reilly KE, Rojo F, She QB, Solit D, Mills GB, Smith D, Lane H, Hofmann F, Hicklin DJ, Ludwig DL et al. 2006 MTOR inhibition induces upstream receptor tyrosine kinase signaling and activates Akt. Cancer Research 66 1500-1508.

Pollak MN, Polychronakos C \& Guyda H 1989 Somatostatin analogue SMS 201-995 reduces serum IGF-I levels in patients with neoplasms potentially dependent on IGF-I. Anticancer Research 9 889-891.
Raica M, Cimpean AM \& Ribatti D 2009 Angiogenesis in pre-malignant conditions. European Journal of Cancer 45 1924-1934.

Righi L, Volante M, Tavaglione V, Billè A, Daniele L, Angusti T, Inzani F, Pelosi G, Rindi G \& Papotti M 2010 Somatostatin receptor tissue distribution in lung neuroendocrine tumours: a clinicopathologic and immunohistochemical study of 218 'clinically aggressive' cases. Annals of Oncology 21 548-555.

Rinke A, Müller HH, Schade-Brittinger C, Klose KJ, Barth P, Wied M, Mayer C, Aminossadati B, Pape UF, Bläker M et al. 2009 Placebo-controlled, double-blind, prospective, randomized study on the effect of octreotide LAR in the control of tumor growth in patients with metastatic neuroendocrine midgut tumors: a report from the PROMID Study Group. Journal of Clinical Oncology 27 4656-4663.

Rubin J, Ajani J, Schirmer W, Venook AP, Bukowski R, Pommier R, Saltz L, Dandona P \& Anthony L 1999 Octreotide acetate long-acting formulation versus open-label subcutaneous octreotide acetate in malignant carcinoid syndrome. Journal of Clinical Oncology 17 600-606.

Srirajaskanthan R, Toumpanakis C, Karpathakis A, Marelli L, Quigley AM, Dusmet M, Meyer T \& Caplin ME 2009 Surgical management and palliative treatment in bronchial neuroendocrine tumours: a clinical study of 45 patients. Lung Cancer 65 68-73.

Tagliati F, Zatelli MC, Bottoni A, Piccin D, Luchin A, Culler MD \& degli Uberti EC 2006 Role of complex cyclin $\mathrm{d} 1 / \mathrm{cdk} 4$ in somatostatin subtype 2 receptormediated inhibition of cell proliferation of a medullary thyroid carcinoma cell line in vitro. Endocrinology 147 3530-3538.

Travis W \& Brambilla E 2004 Pathology and Genetics of Tumours of the Lung, Pleura, Thymus, and Heart. Lyon: IARC Press.

Wulbrand U, Remmert G, Zofel P, Wied M, Arnold R \& Fehmann HC 2000 mRNA expression patterns of insulinlike growth factor system components in human neuroendocrine tumours. European Journal of Clinical Investigation 30 729-739.

Yao JC 2007 Neuroendocrine tumors. Molecular targeted therapy for carcinoid and islet-cell carcinoma. Best Practice \& Research. Clinical Endocrinology \& Metabolism 21 163-172.

Yao JC, Phan AT, Chang DZ, Wolff RA, Hess K, Gupta S, Jacobs C, Mares JE, Landgraf AN, Rashid A et al. 2008 Efficacy of RAD001 (everolimus) and octreotide LAR in advanced low- to intermediate-grade neuroendocrine tumors: results of a phase II study. Journal of Clinical Oncology 26 4311-4318.

Yao JC, Lombard-Bohas C, Baudin E, Kvols LK, Rougier P, Ruszniewski P, Hoosen S, St Peter J, Haas T, Lebwohl D et al. 2010 Daily oral everolimus activity in patients with metastatic pancreatic neuroendocrine tumors after failure of cytotoxic chemotherapy: a phase II trial. Journal of Clinical Oncology 28 69-76. 
Zatelli MC, Piccin D, Bottoni A, Ambrosio MR, Margutti A, Padovani R, Scanarini M, Taylor JE, Culler MD, Cavazzini L et al. 2004 Evidence for differential effects of selective somatostatin receptor subtype agonists on alphasubunit and chromogranin a secretion and on cell viability in human nonfunctioning pituitary adenomas in vitro.

Journal of Clinical Endocrinology and Metabolism 89 5181-5188.

Zatelli MC, Maffei P, Piccin D, Martini C, Rea F, Rubello D, Margutti A, Culler MD, Sicolo N \& degli Uberti EC 2005 Somatostatin analogs in vitro effects in a growth hormonereleasing hormone-secreting bronchial carcinoid. Journal of Clinical Endocrinology and Metabolism 90 2104-2109.

Zatelli MC, Piccin D, Vignali C, Tagliati F, Ambrosio MR, Bondanelli M, Cimino V, Bianchi A, Schmid HA,
Scanarini M et al. 2007 Pasireotide, a multiple somatostatin receptor subtypes ligand, reduces cell viability in non-functioning pituitary adenomas by inhibiting vascular endothelial growth factor secretion. Endocrine-Related Cancer 14 91-102.

Zatelli MC, Minoia M, Molè D, Cason V, Tagliati F, Margutti A, Bondanelli M, Ambrosio MR \& degli Uberti E 2009 Growth hormone excess promotes breast cancer chemoresistance. Journal of Clinical Endocrinology and Metabolism 94 3931-3938.

Zatelli MC, Minoia M, Filieri C, Tagliati F, Buratto M, Ambrosio MR, Lapparelli M, Scanarini M \& degli Uberti EC 2010 Effect of everolimus on cell viability in nonfunctioning pituitary adenomas. Journal of Clinical Endocrinology and Metabolism 95 968-976. 